\title{
Runx1 promotes neuronal differentiation in dorsal root ganglion
}

Azusa Kobayashi, Kouji Senzaki*, Shigeru Ozaki, Masaaki Yoshikawa, Takashi Shiga

Graduate School of Comprehensive Human Sciences, University of Tsukuba, 1-1-1 Tennodai, Tsukuba, Ibaraki 305-8577, Japan.

* Corresponding author (e-mail: ksenzaki@kansei.tsukuba.ac.jp)

\section{Word count}

Abstract $<300$ words, Text words $<40,000$ characters

Running Title: Runx1 promotes neuronal differentiation in DRG

Keywords: Runx1; Knockout mice; Transcription factor; DRG; Neuronal differentiation; Cell proliferation 


\section{Abstract}

Transcription factor Runx1 controls the cell type specification of peptidergic and nonpeptidergic nociceptive dorsal root ganglion (DRG) neurons by repressing TrkA and calcitonin gene-related peptide (CGRP) expression and activating Ret expression during late embryonic and early postnatal periods (Chen et al., 2006; Kramer et al., 2006; Yoshikawa et al., 2007). Because Runx1 is expressed in DRG from early developmental stages, we examined the roles of Runx1 in the proliferation and the neuronal differentiation of DRG cells. We used transgenic Runx1-deficient $\left(\right.$ Runx $\left.1^{-1-}:: T g\right)$ mice which are rescued from early embryonic lethality by selective expression of Runx1 in hematopoietic cells under the control of GATA-1 promoter. We found that TrkA-expressing (TrkA ${ }^{+}$) DRG neurons were decreased at embryonic day (E) 12.5 in contrast to the previous study showing that $\operatorname{TrkA}^{+}$DRG neurons were increased at E17.5 in $\operatorname{Runx1}^{-1-}:$ Tg mice (Yoshikawa et al., 2007). The number of DRG neurons which express neuronal markers $\mathrm{Hu}$, NeuN and Islet1 was also reduced in $\mathrm{RunxI}^{-1-}:$ Tg mice at E12.5, suggesting that the neuronal differentiation was suppressed in these mice. The cell cycle analysis using BrdU/IDU revealed that the number of DRG cells in S-phase and G2/M-phase was increased in $\operatorname{Runx1}^{-/-}:: T g$ mice at E12.5, while the length of


Runx1 negatively controls the proliferation of DRG progenitor cell subpopulation in early embryonic period. Hes1 is a negative regulator of neuronal differentiation (Ishibashi et al., 1995; Tomita et al., 1996), and we found that the number of Hes1 ${ }^{+}$DRG


suggests a novel function that Runx1 activates the neuronal differentiation of DRG cell subpopulation through the repression of Hes1 expression in early embryonic period. 


\section{Introduction}

Runt-related (Runx) transcription factor family has the highly conserved Runt DNA binding domain and comprises three members: Runx1, 2, and 3 in mammal. These Runxs play important roles in cell proliferation and differentiation of various cell types, including hematopoietic cells, osteoblasts, and gastric epithelial cells (Komori et al., 1997; Levanon et al., 2001; Wang et al., 1996; for reviews, see Coffman, 2003; Ito, 2004, 2008). In addition, the anomaly of Runxs has been shown to be involved in various human diseases (Ito et al., 2005, 2008; Li et al., 2002; Otto et al., 1997; for reviews, see Ito, 2004, 2008). Runx1 and Runx3 are also expressed in neuronal subtypes in the embryonic nervous systems (Levanon et al., 2001; Simeone et al., 1995; for reviews, see Inoue et al., 2008; Stifani and Ma, 2009). In the dorsal root ganglion (DRG), Runx1 and Runx3 are expressed in a subpopulation of sensory neurons and control the cell fate specification and the axonal projections of nociceptive and proprioceptive DRG neurons, respectively (Chen et al., 2006a, b; Inoue et al., 2002, 2007; Kramer et al., 2006; Levanon et al., 2002; Marmigère et al., 2006; Nakamura et al., 2008; Yoshikawa et al., 2007; for reviews, see Inoue et al., 2008; Marmigère and Ernfors, 2007; Stifani and Ma, 2009). In particular, Runx1 is initially expressed in nerve growth factor (NGF) receptor TrkA-expressing $\left(\operatorname{TrkA}^{+}\right)$neurons from the early developing period, and is involved in the segregation of these neurons into $\mathrm{TrkA}^{+} /$calcitonin gene-related peptide $(\mathrm{CGRP})^{+}$peptidergic nociceptive neurons and Runx $1^{+} /$glial cell-derived neurotrophic factor (GDNF) receptor Ret $^{+}$nonpeptidergic nociceptive neurons by inhibiting the expression of TrkA and CGRP and promoting the Ret expression in DRG neurons from the late embryonic to postnatal period (Chen et al., 2006b; Kramer et al., 2006; Marmigère et al., 2006; Yoshikawa et al., 2007).

In the nasal cavity, Runx1 is expressed in proliferating cells in the olfactory epithelium. Runx 1 deficiency reduces proliferation and causes premature differentiation of olfactory receptor neuron (ORN) precursors, suggesting that Runx1 coordinates the proliferation and differentiation of ORN precursors (Theriault et al., 2005). In DRG, proliferation of presumptive neurons occurs for several days around E12.5 in the lumbar segments (Lawson and Biscoe, 1979), while Runx1 expression begins in the same segments as early as E12.5 (Chen et al., 2006b), showing the overlap between the cell proliferation and the onset of Runx1 expression in DRG. We have previously shown that Runx1 inhibits proliferation of DRG cells between E11.5 and E13.5, although we did not characterize proliferating cell types as neuronal or non-neuronal cells (Yoshikawa et al., 2007). These results suggest that Runx1 has another roles in the proliferation and differentiation of DRG neurons during the early 
developmental stage, in addition to the subtype specification of nociceptive DRG neurons in the late developmental period.

In the present study, to elucidate roles of Runx1 in the early stage of DRG neuron differentiation, we analyzed the proliferation and the cell fates of DRG neuron in Runx1 deficient mice.

\section{Results}

\section{Transient decrease of DRG neurons in $\operatorname{Runx}^{-/-}:$Tg mice during the early stage of the development}

We have previously shown that the number of $\operatorname{TrkA}^{+}$DRG neurons was increased to $143 \%$ in E17.5 $\operatorname{Runxl}^{-/-}:: T g$ mice as compared with $\operatorname{Runxl}^{+/+}: \because \mathrm{Tg}$ mice (Yoshikawa et al., 2007). Then, we examined the expression of TrkA in early stage of DRG neuronal development (Fig. 1). At E11.5, the number of $\operatorname{TrkA}^{+} \mathrm{DRG}$ neurons was not different

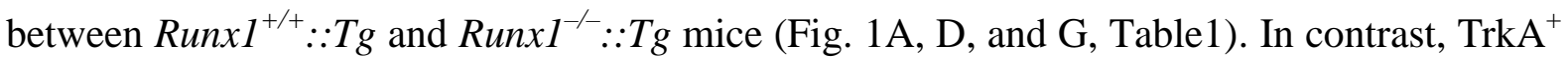
DRG neurons in $\operatorname{Runx1^{-/}}: \because T g$ mice was decreased to $71 \%$ as compared with $R u n x 1^{+/+}: \because T g$ mice at E12.5 (Fig. 1B, E, and G, Table1). At E13.5, the number of TrkA ${ }^{+}$DRG neurons was not changed between $\operatorname{Runx}^{+/+}:: T g$ and $\operatorname{Runx}^{{ }^{-/}}:: T g$ mice (Fig. 1C, F, and G, Table1). There was no significant difference in the number of $\operatorname{TrkC}^{+} \mathrm{DRG}$ neurons between the two genotypes at E12.5 (Fig. 1H-J, Table1).

Next, we examined whether the loss of Runx1 affects the total number of DRG neurons from E11.5 to E13.5, using NeuN as a pan-neuronal marker (Fig. 2, Table1). The number of

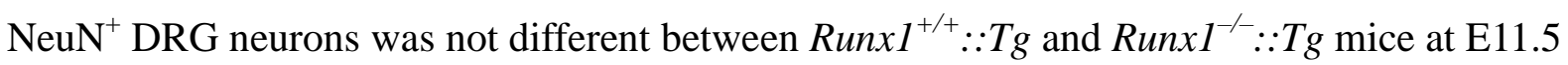
(Fig. 2A, D, and G, Table1). In contrast, the number of $\mathrm{NeuN}^{+}$DRG neurons in Runx $1^{-1}: \because T g$ mice was decreased to $84 \%$ at E12.5 as compared with $R u n x 1^{+/+}: \because T g$ mice (Fig. 2B, E, and G, Table1), and 90\% at E13.5 (Fig. 2C, F, and G, Table1). Because the decrease in the number of $\mathrm{NeuN}^{+}$DRG neurons at E12.5 and E13.5 may be due to the reduction of total DRG cells, we examined the number of total DRG cells using DAPI and the volume of DRG at E12.5 (Fig. 3A-D, Table1). There was no significant difference in the number of DAPI ${ }^{+}$cells

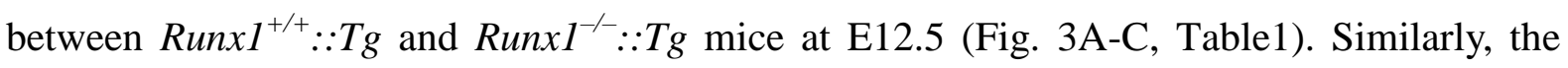
DRG volume was not changed between $R u n x I^{+/+}:: T g\left(44.6 \pm 1.6 \times 10^{5} \mu^{3}{ }^{3}\right)$ and Runx $1^{-1-}:: T g$ mice $\left(45.9 \pm 2.1 \times 10^{5} \mu^{3}\right.$ ) at E12.5 (Fig. 3D). Moreover, to clarify whether the effects of Runx1 deficiency on the apoptosis of DRG, we examined the number of

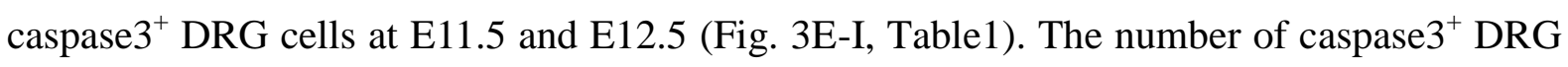


cells was not changed between $R u n x 1^{+/+}:: T g$ and $R u n x 1^{-/}: \because T g$ mice both at E11.5 and E12.5 (Fig. 3E-H, Table1). These results suggest that Runx 1 positively regulates the total number of DRG neurons without affecting the cell survival.

To clarify whether the decrease in the number of $\mathrm{NeuN}^{+}$DRG neuron in $\operatorname{Runx} 1^{-/}:: T g$ mice represents the defects in the neuronal differentiation, we examined the number of DRG neurons at E12.5 using two pan-neuronal markers, Hu RNA-binding protein and Islet1 transcription factor (Akamatsu et al., 2005; Avivi et al., 1999; Wakamatsu et al., 1997) (Fig. 4). Compared with $\operatorname{Runx} 1^{+/+}: \because T g$ mice, the numbers of $\mathrm{Hu}^{+}$and Islet $1^{+}$DRG neurons were decreased to $88 \%$ and $84 \%$ in E12.5 Runx $1^{-1}:: T g$ mice, respectively (Fig. 4, Table1). These results strongly suggest that Runx1 plays roles in promoting the DRG neuronal differentiation in the early developmental period.

\section{Cell cycle analysis of DRG cells in RunxI $^{-1-}:$ Tg mice}

It was reported that the length of cell cycle affects the cell fate determination (Wilcock et

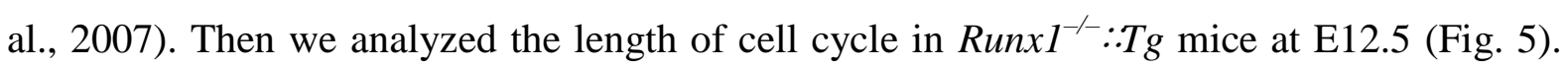
The length of S-phase was calculated by the number of $\mathrm{BrdU}^{+} / \mathrm{IDU}^{+}$S-phase cells and $\mathrm{BrdU}^{-} / \mathrm{IDU}^{+} \mathrm{G} 2 / \mathrm{M}$-phase cells (see Materials and Methods). The number of $\mathrm{BrdU}^{+} / \mathrm{IDU}^{+}$ S-phase DRG cells was increased to $123 \%$ (p <0.05) in $\operatorname{Runx1^{-/-}} \because$ Tg $(1017.3 \pm 59.0)$ as compared with $\operatorname{Runx}^{+/+}:: T g$ mice $(826.8 \pm 58.9)$ (Fig. 5B-D). Similarly, the number of $\mathrm{BrdU}^{-} / \mathrm{IDU}^{+} \mathrm{G} 2 / \mathrm{M}$-phase cells was increased to $159 \%\left(180.3 \pm 20.1\right.$ for $\operatorname{Runxl}^{+/+}:: \mathrm{Tg}$ vs. $286.9 \pm 41.7$ for Runx $1^{-/}: \because T g, \mathrm{p}<0.05$ ) (Fig. 5B, C, and E). By contrast, there was no


$(7.5 \pm 1.2$ h vs. $5.9 \pm 2.2$ h) (Fig. 5 F). These results suggest that Runx 1 suppresses the DRG cell proliferation without effects on the length of S-phase.

\section{Increase of Hes1 $1^{+}$DRG cells in $\operatorname{Runx1^{-1}}:$ Tg mice}

To gain further insight into the roles of Runx1 in the differentiation of DRG neurons, we focused on a basic helix-loop-helix protein Hes1, because Hes1 has been shown to inhibit neuronal differentiation (Cau et al., 2000; Ishibashi et al., 1995; Tomita et el., 1996). At

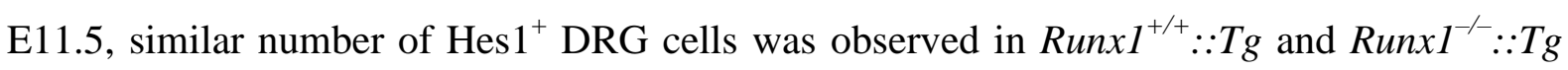
mice $\left(852.3 \pm 11.9\right.$ vs. $896.0 \pm 35.0$ ) (Fig. $6 \mathrm{~A}, \mathrm{~B}$, and E). In contrast, the number of Hes $1^{+}$ cells in $\operatorname{Runx}^{-/}::$Tg DRG was increased to $120 \%(1150.3 \pm 56.1$ vs. $1385.8 \pm 63.1$, p <0.05) compared with $\operatorname{RunxI}^{+/+}:: T g$ DRG at E12.5 (Fig. 6C, D, and E). Next, we examined the co-localization of Runx1 and Hes1 in $R u n x 1^{+/+}:: T g$ DRG at E12.5. Many Runx $1^{+}$DRG cells did not express Hes1 (Fig. 6F-H; red [Runx1 alone]=78, green [Hes1 alone]=22, yellow 
[co-expression]=22), suggesting that Runx1 may inhibit the Hes1 expression in DRG cells. Furthermore, we examined the co-localization of Runx1 and Notch1 intracellular domain (NICD), because Hes1 is downstream in the Notch signaling pathway. In Runx $1^{+/+}:: T g$ DRG at E12.5, many Runx $1^{+}$DRG cells co-expressed activated-Notch1 (Fig. 7), suggesting that Runx1 may regulate Hes1 through activating Notch1 within the same DRG cells. Taken together, these results suggest that Runx1 may regulate the neuronal differentiation of DRG cells by inhibiting the Hes1 expression at E12.5.

\section{Discussion}

In the present study, we examined the roles of Runx 1 in the proliferation and differentiation of DRG neurons during the early embryonic period. We found that the Runx 1 deficiency decreased the number of DRG neurons which express TrkA and three neuronal markers, $\mathrm{Hu}$, NeuN, and Islet1, while the number of DAPI ${ }^{+}$total DRG cells and caspase $3^{+}$apoptotic cells was not changed at E12.5. In addition, we showed that Runx1 deficiency increased both proliferating DRG cells and Hes1 expression in DRG. Taken together, it was suggested that Runx1 promotes the DRG neuronal differentiation by suppressing Hes1 expression at restricted time window in the early developmental stage.

\section{Roles of Runx1 in the cell proliferation and neuronal differentiation at early stage of DRG development}

It was reported that Runx1 is initially expressed in $\operatorname{TrkA}^{+}$DRG neurons and subsequently segregates these neurons into $\operatorname{Runx}^{+} / \operatorname{Ret}^{+}$nonpeptidergic nociceptive neurons and $\mathrm{TrkA}^{+} / \mathrm{CGRP}^{+}$peptidergic nociceptive neurons by repressing the expression of TrkA and CGRP and activating c-Ret expression from the late embryonic through postnatal period (Chen et al., 2006b; Kramer et al., 2006; Marmigère et al., 2006; Yoshikawa et al., 2007). Although Runx1 plays crucial roles in the diversification of nociceptive DRG neurons from the late embryonic period, Runx1 is expressed as early as E12.5 (Chen et al., 2006b, Fig. S1), when there are many proliferating cells in DRG (Lawson and Biscoe, 1979). In addition, we have previously shown that Runx 1 deficiency increased the proliferation of DRG cells during E11.5 and E13.5 (Yoshikawa et al., 2007). Taken together, these results suggest that Runx1 may be involved in the proliferation and/or differentiation of DRG neurons at early embryonic stage. 
The present study revealed that the number of DRG neurons which express $\mathrm{Hu}, \mathrm{NeuN}$, Islet1, or TrkA was decreased in Runx1-deficient mice at E12.5, independent of the DAPI ${ }^{+}$ total cell number and the caspase $3^{+}$apoptotic cells. Hu is a RNA-binding protein expressed during neurogenesis and promotes neuronal differentiation (Akamatsu et al., 2005; Wakamatsu et al., 1997). NeuN is a pan-neuronal marker expressed in differentiated neuron, and Islet1 is a transcription factor expressed in the process of neuronal specification of selected neurons including DRG neurons (Avivi et al., 1999). Considering the characteristics of these molecules, the present findings suggest that Runx1 is involved in promoting neuronal differentiation from the early stages of the neurogenesis. In addition, the cell cycle analysis suggested that Runx1 decreases the proliferation of DRG cells without changes in cell cycle length. Taken together, these results suggest that Runx1 has a role in suppressing the proliferation of DRG cells and promoting DRG neuronal differentiation.

In the present study, $\mathrm{TrkA}^{+}$and $\mathrm{NeuN}^{+}$neurons were decreased transiently at E12.5 but not E11.5 in $\operatorname{Runx}^{-/}: \because T g$ DRG. The failure of effects of Runx1 deficiency at E11.5 seems to be due to the insufficient expression of Runx 1 to cause significant changes in the number of $\mathrm{TrkA}^{+}$and $\mathrm{NeuN}^{+} \mathrm{DRG}$ neurons, because it was reported that Runx1 expression does not begin until E12.5 in DRG (Chen et al., 2006b). We previously reported that the number of TrkA $^{+}$neurons was increased in Runx $^{-/}: \because$ Tg DRG at E17.5 (Yoshikawa et al., 2007). This effect was explained by the suppression of TrkA expression by Runx1 (Chen et al., 2006b; Yoshikawa et al., 2007). In contrast, the present study showed the contradictory results that the number of $\operatorname{TrkA}^{+}$neurons was reduced in $\operatorname{Runx}^{-/-}: \because \mathrm{Tg}$ at E12.5. There seem to be at least two possibilities for the early decrease of $\operatorname{TrkA}^{+}$neurons. First, Runx 1 deficiency suppresses the DRG neuronal differentiation, which subsequently results in the reduction of the number of $\operatorname{TrkA}^{+}$neurons at E12.5. In this case, Runx 1 is not necessarily involved in the direct regulation of TrkA expression. This is highly possible considering that TrkA is expressed in postmitotic neurons committed to a sensory neuronal fate (Marmigère and Ernfors, 2007). The second possibility is that Runx 1 induces the TrkA expression directly. In accordance with the second possibility, it was reported that overexpression of Runx 1 induces precocious TrkA expression in migrating neural crest cells without promoting neuronal differentiation, and that the number of $\operatorname{TrkA}^{+}$DRG neurons is decreased by Runx 1 inhibition with transfection of Runxl siRNA to DRG neurons in early developing chick embryos (Marmigère et al., 2006). Therefore, Runx 1 may have dual functions in the regulation of TrkA expression depending on the developmental stages, activation at the early stage and suppression at later stage. In this case, different co-factors may be involved in the regulation of TrkA expression by Runx 1 . 
Further analyses on the regulatory mechanisms of TrkA expression by Runx1 are needed to clarify the developmental context-dependent functions.

There seems to be some discrepancy in the effects of Runx1 inactivation on TrkA expression in previous reports. It was reported that Runx 1 inactivation reduces of TrkA ${ }^{+}$ neuronal number in early chick DRG and in early developing mouse trigeminal ganglion (Theriault et al., 2004; Marmigère et al., 2006). In contrast, we and Chen et al. reported that Runx1 inactivation increases $\operatorname{TrkA}^{+}$neurons in mouse DRG at late embryonic and postnatal stages (Chen et al., 2006b; Yoshikawa et al., 2007). The present study showed that Runx 1 inactivation reduces TrkA $^{+}$neurons at the early embryonic period, in contrast to the increase of $\operatorname{TrkA}^{+}$neurons at late embryonic stage in the same mouse strain (Yoshikawa et al., 2007). Therefore, it is possible the discrepancy regarding the Runx1 function in TrkA expression may be due to the differences of the developmental stages examined.

It was reported that Runx1 promotes the cell proliferation of ORN precursors in the olfactory epithelium (Theriault et al., 2005). In contrast, the present study showed the opposite function of Runx1 in suppression of the proliferation of DRG cells. In the olfactory epithelium, Runx1 is expressed in proliferating cells (Theriault et al., 2004). By contrast, in DRG, Runx1 is expressed in post-mitotic cells undergoing neuronal differentiation but not proliferating cells (Chen et al., 2006b; Marmigère et al., 2006; Yoshikawa et al., 2007, Fig. $\mathrm{S} 1)$. Therefore, it is likely that Runx 1 is different in the expression between proliferating ORN precursors and postmitotic DRG neurons and that Runx1 has different functions between these cells.

\section{Possible involvement of Hes1 in mediating the effects of Runx1 in the neuronal differentiation}

The present study suggested that Runx1 promotes the differentiation of DRG neurons. To gain an insight into the molecular mechanisms mediating actions of Runx1 in the neuronal differentiation, we examined the expression of Hes1 which has been shown to suppress neuronal differentiation (Cau et al., 2000; Ishibashi et al., 1995; Iso et al., 2003; Guo et al.,


possibility that the promotion of neuronal differentiation by Runx 1 is mediated by the suppression of Hes1 expression. However, the regulatory mechanisms of Hes1 expression by Runx 1 remain to be examined. It is possible that Runx $1^{+}$DRG neurons themselves do not express Hes1 and suppress Hes1 expression in cells undergoing neuronal differentiation which adjoin the Runx $1^{+}$DRG neurons (Fig. 8A). Alternatively, Runx1 suppresses Hes1 expression cell-autonomously within the same cells (Fig. 8B). The first regulatory 
mechanism seems to be plausible in DRG, considering the previous study showing that Runx1 is expressed in postmitotic (therefore Hes1-negative or weakly positive) DRG neurons. However, we could not exclude the second possibility that Hes1 is downstream to Runx1. In various types of cells including the olfactory epithelial cells, it has been shown that Runx 1 cofactor CBF-1 is involved in the regulation of Hes1 expression (Cau et al., 2000; Guo et al., 2008; Ishibashi et al., Iso et al., 2003; 1995; Tomita et al., 1996).

To determine the mechanisms of the regulation of Hes1 expression by Runx1, we examined the co-localization of Runx 1 and Hes1. The immunohistochemical analysis showed that many Runx $1^{+}$DRG cells did not express Hes1 at E12.5, but there were still some cell populations which expressed only Hes1 or both Runx1 and Hes1. We also examined Notch1 expression in Runx $1^{+}$DRG cells. Hes 1 is downstream of the Notch signaling pathway. When Delta-like1 binds to Notch1, Notch1 intracellular domain (NICD) is disconnected from Notch1 and translocated into nucleus. NICD then binds the nuclear protein CBF-1 and controls Hes1 transcription (Fig. 8C, Iso et al., 2003). When we examined co-localization of Runx1 and NICD, many Runx $1^{+}$DRG cells co-expressed NICD (activated-Notch1) at E12.5, suggesting that Runx1 may regulate Hes1 within the same cells. Taken together, it is possible that Runx1 inhibits the expression of Hes1 by binding to the transcriptional regulatory domain of Hes1 in DRG cells in $R u n x 1^{+/+}:: T g$ mice at E12.5. In Runx $1^{-/}:: T g$ mice, Runx1 does not bind the transcriptional regulatory domain of Hes1 and DRG neurons continue to express Hes1 (Fig. 8C). Therefore neuronal differentiation of DRG cells was suppressed in $\operatorname{Runx} 1^{-/}: \because T g$ mice compared with $\operatorname{Runx}^{+/+}:: T g$ mice at E12.5. Hes1 is expressed before Runx1 expression, and Runx1 may be under way to repress the Hes1 expression at E12.5. Accordingly, $22 \%$ of Runx $1^{+}$cells and $50 \%$ of $\mathrm{Hes}^{+}$cells co-express Hes 1 and Runx1, respectively. Molecular approaches such as ChIP assay are needed to determine the mechanisms underlying the regulation of Hes1 expression by Runx1.

In summary, the present study suggested novel functions of Runx 1 in the regulation of proliferation and neuronal differentiation of DRG neurons during the early stage of the development. Although the suppression of Hes1 expression may be involved in the promotion of neuronal differentiation by Runx1, further studies are needed to clarify the regulatory mechanisms. 


\section{Experimental Methods}

\section{Animal maintenance and genotyping}

The strategy used to inactivate Runxl in the mouse germline and rescue Runxl gene knockout mice from embryonic lethality by expressing the Runxl transgene in erythroid cells specifically was described previously (Okada et al., 1998; Okuda et al., 1996; Yokomizo et al., 2007, Yoshikawa et al., 2007). Mice were bred in a clean room in the Laboratory Animal

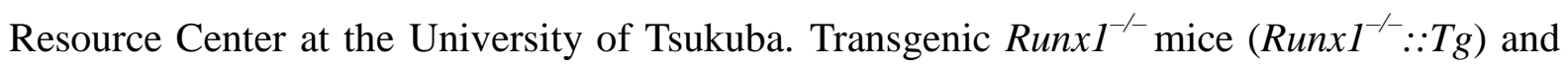

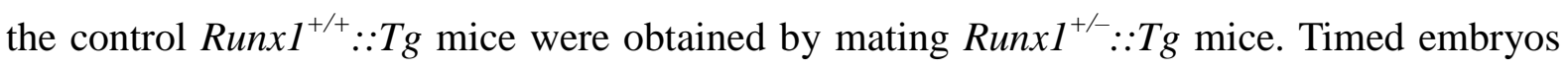
were obtained by overnight mating, and the morning when the vaginal plug was observed was considered E0.5. The stages of mouse embryos were confirmed according to Kaufman (Kaufman, 1992). Runx1 mutant mice were genotyped using PCR as described previously (Okada et al., 1998) and a pair of primers, RUNT S1 (5'-AGCATGGTGGAGGTACTAGC-3') and RUNT AS1 (5'-GGTCGTTGAATCTCGCTACC-3') was used for Runxl transgene detection. All experiments followed the Guide for the Care and Use of Laboratory Animals described by the National Institutes of Health (USA) and were approved by the Animal Experimentation Committee of the University of Tsukuba.

\section{Immunohistochemistry}

For cryostat sections, E11.5 and E12.5 whole mouse embryos were immersed two overnights, and E13.5 were immersed overnight at $4^{\circ} \mathrm{C}$ in a fixative containing $4 \%$ paraformaldehyde in $0.1 \mathrm{M}$ phosphate buffer ( $\mathrm{pH}$ 7.4). Whole mouse embryos were immersed in $0.1 \mathrm{M} \mathrm{PB}$ containing $20 \%$ sucrose overnight on ice and frozen in Tissue-Tek O. C. T. compound (Sakura Finetek, Japan). Ten $\mu \mathrm{m}$ transverse serial sections of the trunk at thoracic segments were cut using a cryostat (HM 500 OM; Microm, Germany) and collected onto MAS-coated glass slides (Matsunami Glass, Japan) and air-dried for $1 \mathrm{~h}$. If needed, sections were subjected to heat-induced epitope retrieval by heating to $105^{\circ} \mathrm{C}$ for $8 \mathrm{~min}$ in Dako REAL ${ }^{\mathrm{TM}}$ Target Retrieval Solution (Dako). After treatment for $30 \mathrm{~min}$ at room temperature (RT) with $0.3 \% \mathrm{H}_{2} \mathrm{O} 2$ in methanol to eliminate endogenous peroxidase reaction, the sections were incubated for $1 \mathrm{~h}$ at RT in a blocking solution containing 5\% normal goat serum or 5\% normal horse serum and $0.15 \%$ Triton X-100 in phosphate-buffered saline.

For immunohistochemical analysis, the following specific antibodies were used: mouse anti-NeuN (Chemicon; 1:6000), mouse anti-Islet1 (Developmental Studies Hybridoma Bank; 1:200), rabbit anti-TrkA (RTA; a gift from Dr. L. F. Reichardt, University of California, San 
Francisco, CA; 1:4000, Chemicon; 1:2000), goat anti-TrkC (R\&D Systems; 1:2000), rabbit anti-Hes1 (Millipore; 1:2000), biotinylated mouse anti-Hu (Invitrogen; 1:400), rabbit anti-caspase3 (Promega; 1:2000) and rabbit anti-activated Notch1 (Abcam; 1:200) antibodies. The sections were incubated for 24 to $48 \mathrm{~h}$ at $4^{\circ} \mathrm{C}$ with each of the primary antibodies. For single staining, the sections were incubated with anti-TrkA, anti-Hes1 or anti-TrkC antibody as described above, followed by the incubation with a biotinylated anti-rabbit or goat IgG antibody (Vector laboratories; 1:500) for $1 \mathrm{~h}$ at RT, and the peroxidase-conjugated avidin-biotin complex (ABC kit elite, Vector Laboratories; 1:100) for $30 \mathrm{~min}$ at RT. The sections incubated with anti-NeuN or anti-Islet1 were incubated with a HRP conjugated anti-rabbit IgG antibody (MBL; 1:600) for $1.5 \mathrm{~h}$ at RT. The sections incubated with biotinylated mouse anti-Hu were incubated with the peroxidase-conjugated avidin-biotin complex (1:100) for $30 \mathrm{~min}$ at RT. The positive reactions were visualized with ImmunoPure Metal Enhanced DAB Substrate kit (Pierce) for $7 \mathrm{~min}$ at RT. The sections incubated with anti-caspase3 were incubated with Alexa Fluor 488 labeled anti-rabbit IgG antibody (Invitrogen; 1:1000) for $1.5 \mathrm{~h}$ at RT. For double staining, cryostat sections were incubated with mouse anti-Runx1 and rabbit anti-Hes1 antibody two overnight at $4{ }^{\circ} \mathrm{C}$, followed by incubation with Alexa Fluor 594 labeled anti-mouse IgG and Alexa Fluor 488 labeled anti-rabbit IgG antibody (Invitrogen; 1:1000) for $1.5 \mathrm{~h}$ at RT. Nuclear staining was performed with 4', 6-diamidino-2-phenylindole (DAPI, Invitrogen; $100 \mathrm{ng} / \mathrm{ml}$ ) for $10 \mathrm{~min}$ at RT. Images of immunostained sections were collected on a LSM510META confocal microscope (Carl Zeiss). Samples from $R u n x I^{-/}:: T g$ and $R u n x I^{+/+}:: T g$ littermates were processed simultaneously for immunohistochemistry.

\section{Cell cycle analysis}

Cell cycle analysis was based on a previous paper (Martynoga et al., 2005). To estimate the cell cycle parameters; the number of S-phase and G2/M-phase cells and the length of S-phase, pregnant female mice 12.5 days after mating were injected intraperitoneally with 5'-Indo-2'-deoxyuridine (IDU, Sigma, $50 \mathrm{mg} / \mathrm{kg}$ ) at $\mathrm{T}=0 \mathrm{~h}$ to label all cells in S-phase at start of the experiment (Fig. 5A). At $\mathrm{T}=1.5 \mathrm{~h}, 5$ '-Bromo-2'-deoxyuridine (BrdU, Sigma, 50 $\mathrm{mg} / \mathrm{kg}$ ) was injected and the embryos were fixed after $0.5 \mathrm{~h}$, sufficient to label the S-phase cells at the end of the labeling period (Nowakowski et al., 1989). During the $1.5 \mathrm{~h}$ interval when cells are exposed to IDU but not BrdU, some of the initial S-phase cells would leave S-phase and consequently labeled with IDU (Leaving cells). For double immunostaining of BrdU and IDU, mouse anti-BrdU/IDU antibody (clone B44, 1:100 in blocking solution; Becton Dickinson) which recognizes both BrdU and IDU, and rat anti-BrdU antibody (clone 
BU1/75, 1:400; Abcam) which recognizes BrdU but not IDU were used. The cryostat sections were incubated overnight at $4^{\circ} \mathrm{C}$ with mouse anti-BrdU/IDU and rat anti-BrdU antibody, followed by Alexa Fluor 488 labeled anti-mouse IgG (Invitrogen; 1:1000) and Alexa Fluor 594 labeled anti-rat IgG antibody (Invitrogen; 1:1000) for $1.5 \mathrm{~h}$ at RT. BrdU/IDU double labeled cells were S-phase cells (S cells) and IDU single labeled cells G2/M-pahse cells ( $\mathrm{L}$ cells). The length of S-phase (Ts) was calculated as follows: Ts $=\mathrm{S}$ cells $/ \mathrm{L}$ cells $\times$ $1.5 \mathrm{~h}$.

\section{Cell counting, Measurement of DRG volume and statistical analysis}

DRGs at thoracic segments were serially sectioned at $10 \mu \mathrm{m}$, and all the sections containing a particular DRG were immunostained by a single antibody and used for cell counting. For counts of $\mathrm{Hu}^{+}$and Islet1 ${ }^{+}$DRG neurons, DRGs in the fifth thoracic segment (Th5) and Th7 were serially sectioned, respectively. Serial sections of Th11 DRGs were used for counts of $\mathrm{DAPI}^{+}, \mathrm{TrkA}^{+}, \mathrm{TrkC}^{+}, \mathrm{IDU}^{+}, \mathrm{BrdU}^{+}$and Hes $1^{+}$DRG cells, and those of Th13 DRGs were used for counts of $\mathrm{NeuN}^{+}$and caspase $3^{+}$DRG cells. Images of DRG sections were captured with a CCD camera on an Axioplan2 microscope (Carl Zeiss) or an LSM510META confocal microscope (Carl Zeiss) using a 20x objective.-As described previously (Nakamura et al., 2008), cells were counted if they contained a nucleus and had a signal intensity in the cytoplasm or nucleus that was more than 2.5 -fold above the noise level for that tissue section. For measurement of DRG volume, $10 \mu \mathrm{m}$-thick serial sections containing whole DRGs (Th11) at E12.5 were used. The DRG areas in each section were measured and the DRG volume calculated using ImageJ image analysis software (NIH). Quantitative analyses were performed on three pairs of embryos from three independent pregnant mice. Statistical analyses were performed using the $F$ test, followed by the Student's $t$ test. Differences were considered significant if the probability of error was less than 5\%. All results are expressed as the mean \pm SEM.

\section{Acknowledgements}

We are grateful to Drs. Yoshiaki Ito and Masanobu Satake for $R u n x 1^{-/}: \because T g$ mice. We thank Dr. L.F. Reichardt for providing the antibodies against TrkA. This study was supported by a Grant-in-Aid for Scientific Research from the 21st Century COE Program from the Ministry of Education, Culture, Sports, Science, and Technology (MEXT) of Japan to S.O., M.Y., and T.S., a Grant-in-Aid for Scientific Research (C) to K.S. from MEXT, and a Grant-in-Aid for Scientific Research (B) to T.S. from MEXT. 


\section{References}

Akamatsu, W., Fujihara, H., Mitsuhashi, T., Yano, M., Shibata, S., Hayakawa, Y., Okano, H.J., Sakakibara, S., Takano, H., Takano, T., Takahashi, T., Noda, T., Okano, H., 2005. The RNA-binding protein $\mathrm{HuD}$ regulates neuronal cell identity and maturation. Proc. Natl. Acad. Sci. U S A 102, 4625-4630.

Avivi, C., Goldstein, R.S., 1999. Differential expression of Islet-1 in neural crest-derived ganglia: Islet- $1^{+}$dorsal root ganglion cells are post-mitotic and Islet- $1^{+}$sympathetic ganglion cells are still cycling. Brain Res. Dev. Brain Res. 115, 89-92.

Cau, E., Gradwohl, G., Casarosa, S., Kageyama, R., Guillemot, F., 2000. Hes genes regulate sequential stages of neurogenesis in the olfactory epithelium. Development 127, 2323-2332.

Chen, A.I., de Nooij, J.C., Jessell, T.M., 2006a. Graded activity of transcription factor Runx3 specifies the laminar termination pattern of sensory axons in the developing spinal cord. Neuron 49, 395-408.

Chen, C.L., Broom, D.C., Liu, Y., de Nooij, J.C., Li, Z., Cen, C., Samad, O.A., Jessell, T.M., Woolf, C.J., Ma, Q., 2006b. Runx1 determines nociceptive sensory neuron phenotype and is required for thermal and neuropathic pain. Neuron 49, 365-377.

Coffman, J.A., 2003. Runx transcription factors and the developmental balance between cell proliferation and differentiation. Cell Biol. Int. 27, 315-324.

Fariñas, I., Yoshida, C.K., Backus, C., Reichardt, L.F., 1996. Lack of neurotrophin-3 results in death of spinal sensory neurons and premature differentiation of their precursors. Neuron 17, 1065-1078.

Fariñas, I., Wilkinson, G.A., Backus, C., Reichardt, L.F., Patapoutian, A., 1998. Characterization of neurotrophin and Trk receptor functions in developing sensory ganglia: direct NT-3 activation of TrkB neurons in vivo. Neuron 21, 325-334.

Guo, Y., Maillard, I., Chakraborti, S., Rothenberg, E.V., Speck, N.A., 2008. Core binding factors are necessary for natural killer cell development and cooperate with Notch signaling 
during T-cell specification. Blood 112, 480-492.

Inoue, K., Ozaki, S., Shiga, T., Ito, K., Masuda, T., Okado, N., Iseda, T., Kawaguchi, S., Ogawa, M., Bae, S.C., Yamashita, N., Itohara, S., Kudo, N., Ito, Y., 2002. Runx3 controls the axonal projection of proprioceptive dorsal root ganglion neurons. Nat. Neurosci. 5, 946-954.

Inoue, K., Ito, K., Osato, M., Lee, B., Bae, S.C., Ito, Y., 2007. The transcription factor Runx3 represses the neurotrophin receptor TrkB during lineage commitment of dorsal root ganglion neurons. J. Biol. Chem. 282, 24175-24184.

Inoue, K., Shiga, T., Ito, Y., 2008. Runx transcription factors in neuronal development. Neural Develop. 3, 20.

Ishibashi, M., Ang, S.L., Shiota, K., Nakanishi, S., Kageyama, R., Guillemot, F., 1995. Targeted disruption of mammalian hairy and enhancer of split homolog-1 (HES1) leads to up-regulation of neural helix-loop-helix factors, premature neurogenesis, and severe neural tube defects. Genes Dev. 9, 3136-3148.

Iso, T., Kedes, L., Hamamori, Y., 2003. HES and HERP families: multiple effectors of the Notch signaling pathway. J. Cell Physiol. 194, 237-255.

Ito, K., Liu, Q., Salto-Tellez, M., Yano, T., Tada, K., Ida, H., Huang, C., Shah, N., Inoue, M., Rajnakova, A., Hiong, K.C., Peh, B.K., Han, H.C., Ito, T., Teh, M., Yeoh, K.G., Ito, Y., 2005. RUNX3, a novel tumor suppressor, is frequently inactivated in gastric cancer by protein mislocalization. Cancer Res. 65, 7743-7750.

Ito, K., Lim, A.C., Salto-Tellez, M., Motoda, L., Osato, M., Chuang, L.S., Lee, C.W., Voon, D.C., Koo, J.K., Wang, H., Fukamachi, H., Ito, Y., 2008. RUNX3 attenuates beta-catenin/T cell factors in intestinal tumorigenesis. Cancer Cell 14, 226-237.

Ito, Y., 2004. Oncogenic potential of the RUNX gene family: 'overview'. Oncogene 23, 4198-4208.

Ito, Y., 2008. Runx genes in development and cancer: Regulation of viral gene expression and the discovery of Runx family genes. Advances in Cancer Research 99, 33-76. 
Kaufman, M.H., 1992. The atlas of mouse development. Academic Press, San Diego.

Komori, T., Yagi, H., Nomura, S., Yamaguchi, A., Sasaki, K., Deguchi, K., Shimizu, Y., Bronson, R.T., Gao, Y.H., Inada, M., Sato, M., Okamoto, R., Kitamura, Y., Yoshiki, S., Kishimoto, T., 1997. Targeted disruption of Cbfa1 results in a complete lack of bone formation owing to maturational arrest of osteoblasts. Cell 89, 755-764.

Kramer, I., Sigrist, M., de Nooij, J.C., Taniuchi, I., Jessell, T.M., Arber, S., 2006. A role for Runx transcription factor signaling in dorsal root ganglion sensory neuron diversification. Neuron 49, 379-393.

Lawson, S.N., Biscoe, T.J., 1997. Development of mouse dorsal root ganglia: an autoradiographic and quantitative study. J. Neurocytol. 8, 379-393.

Levanon, D., Brenner, O., Negreanu, V., Bettoun, D., Woolf, E., Eilam, R., Lotem, J., Gat, U., Otto, F., Speck, N., Groner, Y., 2001. Spatial and temporal expression pattern of Runx3 (Aml2) and Runx1 (Aml1) indicates non-redundant functions during mouse embryogenesis. Mech. Dev. 109, 413-417.

Levanon, D., Bettoun, D., Harris-Cerruti, C., Woolf, E., Negreanu, V., Eilam, R., Bernstein, Y., Goldenberg, D., Xiao, C., Fliegauf, M., Kremer, E., Otto, F., Brenner, O., Lev-Tov, A., Groner, Y., 2002. The Runx3 transcription factor regulates development and survival of TrkC dorsal root ganglia neurons. EMBO J. 21, 3454-3463.

Li, Q.L., Ito, K., Sakakura, C., Fukamachi, H., Inoue, K., Chi, X.Z., Lee, K.Y., Nomura, S., Lee, C.W., Han, S.B., Kim, H.M., Kim, W.J., Yamamoto, H., Yamashita, N., Yano, T., Ikeda, T., Itohara, S., Inazawa, J., Abe, T., Hagiwara, A., Yamagishi, H., Ooe, A., Kaneda, A., Sugimura, T., Ushijima, T., Bae, S.C., Ito, Y., 2002. Causal relationship between the loss of RUNX3 expression and gastric cancer. Cell 109, 113-124.

Marmigère, F., Montelius, A., Wegner, M., Groner, Y., Reichardt, L.F., Ernfors, P., 2006. The Runx1/AML1 transcription factor selectively regulates development and survival of TrkA nociceptive sensory neurons. Nat. Neurosci. 9, 180-187. 
Marmigère, F., Ernfors, P., 2007. Specification and connectivity of neuronal subtypes in the sensory lineage. Nat. Rev. Neurosci. 8, 114-127.

Martynoga, B., Morrison, H., Price, D.J., Mason, J.O., 2005. Foxg1 is required for specification of ventral telencephalon and region-specific regulation of dorsal telencephalic precursor proliferation and apoptosis. Dev. Biol. 283, 113-127.

Nakamura, S., Senzaki, K., Yoshikawa, M., Nishimura, M., Inoue, K., Ito, Y., Ozaki, S., Shiga, T., 2008. Dynamic regulation of the expression of neurotrophin receptors by Runx3. Development 135, 1703-1711.

Nowakowski, R.S., Lewin, S.B., Miller, M.W., 1989. Bromodeoxyuridine immunohistochemical determination of the lengths of the cell cycle and the DNA-synthetic phase for an anatomically defined population. J. Neurocytol. 18, 311-318.

Okada, H., Watanabe, T., Niki, M., Takano, H., Chiba, N., Yanai, N., Tani, K., Hibino, H., Asano, S., Mucenski, M.L., Ito, Y., Noda, T., Satake, M., 1998. AML1(-/-) embryos do not express certain hematopoiesis-related gene transcripts including those of the PU.1 gene. Oncogene 17, 2287-2293.

Okuda, T., van Deursen, J., Hiebert, S.W., Grosveld, G., Downing, J.R., 1996. AML1, the target of multiple chromosomal translocations in human leukemia, is essential for normal fetal liver hematopoiesis. Cell 84, 321-330.

Otto, F., Thornell, A.P., Crompton, T., Denzel, A., Gilmour, K.C., Rosewell, I.R., Stamp, G.W., Beddington, R.S., Mundlos, S., Olsen, B.R., Selby, P.B., Owen, M.J., 1997. Cbfa1, a candidate gene for cleidocranial dysplasia syndrome, is essential for osteoblast differentiation and bone development. Cell 89, 765-771.

Simeone, A., Daga, A., Calabi, F., 1995. Expression of runt in the mice embryo. Dev. Dyn. $203,61-70$.

Stifani, S., Ma, Q., 2009. 'Runxs and regulations' of sensory and motor neuron subtype differentiation: Implications for hematopoietic development. Blood Cells, Mol. Diseases. 43, 20-26. 
Theriault, F.M., Roy, P., Stifani, S., 2004. AML1/Runx1 is important for the development of hindbrain cholinergic branchiovisceral motor neurons and selected cranial sensory neurons. Proc. Natl. Acad. Sci. U S A 101, 10343-10348.

Theriault, F.M., Nuthall, H.N., Dong, Z., Lo, R., Barnabe-Heider, F., Miller, F.D., Stifani, S., 2005. Role for Runx1 in the proliferation and neuronal differentiation of selected progenitor cells in the mammalian nervous system. J. Neurosci. 25, 2050-2061.

Tomita. K., Ishibashi, M., Nakahara, K., Ang, S.L., Nakanishi, S., Guillemot, F., Kageyama, R., 1996. Mammalian hairy and enhancer of split homolog 1 regulates differentiation of retinal neurons and is essential for eye morphogenesis. Neuron, 16, 723-734.

Wakamatsu, Y., Weston, J.A., 1997. Sequential expression and role of Hu RNA-binding proteins during neurogenesis. Development 124, 3449-3460.

Wang, Q., Stacy, T., Binder, M., Marin-Padilla, M., Sharpe, A.H., Speck, N.A., 1996. Disruption of the Cbfa2 gene causes necrosis and hemorrhaging in the central nervous system and blocks definitive hematopoiesis. Proc. Natl. Acad. Sci. U S A 93, 3444-3449.

Yokomizo, T., Takahashi, S., Mochizuki, N., Kuroha, T., Ema, M., Wakamatsu, A., Shimizu, R., Ohneda, O., Osato, M., Okada, H., Komori, T., Ogawa, M., Nishikawa, S., Ito, Y., Yamamoto, M., 2007. Characterization of GATA-1(+) hemangioblastic cells in the mouse embryo. EMBO J. 26,184-196.

Yoshikawa, M., Senzaki, K., Yokomizo, T., Takahashi, S., Ozaki, S., Shiga, T., 2007. Runx1 selectively regulates cell fate specification and axonal projections of dorsal root ganglion neurons. Dev. Biol. 303, 663-674. 


\section{Figure legends}

Figure 1. Transient decrease of $\operatorname{TrkA}^{+}$DRG without changes of $\operatorname{TrkC}^{+}$DRG neurons in

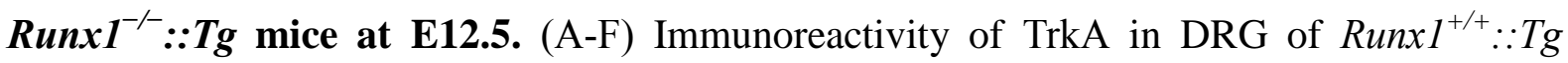
(A-C) and $\operatorname{Runx}^{-/-}: \because \operatorname{Tg}(\mathrm{D}-\mathrm{F})$ mice at E11.5 (A, D), E12.5 (B, E), E13.5 (C, F). Boxed areas of immunoreactive neurons are shown at higher magnification in the insets at the left bottom of each panel. (G) Quantification of the number of $\operatorname{TrkA}^{+} \mathrm{DRG}$ neurons in $R u n x 1^{+/+}: \because T g$ (white bars) and Runx $1^{-/-}:$Tg (black bars) mice from E11.5 to E13.5. (H, I) Immunoreactivity of TrkC in DRG of Runx $1^{+/+}: \because \operatorname{Tg}(\mathrm{H})$ and $R u n x 1^{-/-}: \because \operatorname{Tg}(\mathrm{I})$ mice at E12.5. Boxed areas of immunoreactive neurons are shown at higher magnification in the insets at the left bottom of each panel. (J) Quantification of the number of $\operatorname{TrkC}^{+} \mathrm{DRG}$ neurons in $\operatorname{Runx} 1^{+/+}: \because \operatorname{Tg}$ (white bar) and $\operatorname{Runx1^{-/-}}: \because T g$ (black bar) mice at E12.5. Data are shown as mean \pm SEM; $* * * p<0.001$. Scale bars: $100 \mu \mathrm{m}$ in A-F, I.

Figure 2. Decrease of NeuN ${ }^{+}$neurons in $\operatorname{Runx}^{-/}::$Tg DRG during early development. (A-F) Immunoreactivity of NeuN in DRG of $R u n x 1^{+/+}: \because \operatorname{Tg}(\mathrm{A}-\mathrm{C})$ and $R u n x 1^{-/-}: \because \operatorname{Tg}$ (D-F) mice at E11.5 (A, D), E12.5 (B, E), E13.5 (C, F). Boxed areas of immunoreactive neurons are shown at higher magnification in the insets at the left bottom of each panel. (G) Quantification of the number of $\mathrm{NeuN}^{+} \mathrm{DRG}$ neurons in $R u n x 1^{+/+}:: T g$ (white bars) and $\operatorname{Runx}^{-/-}: \because T g$ (black bars) mice from E11.5 to E13.5. Data are shown as mean \pm SEM; $* p<0.05, * * p<0.01$. Scale bars: $100 \mu \mathrm{m}$ in A-F.

Figure 3. No changes in the total DRG cells, the DRG volume and the number of

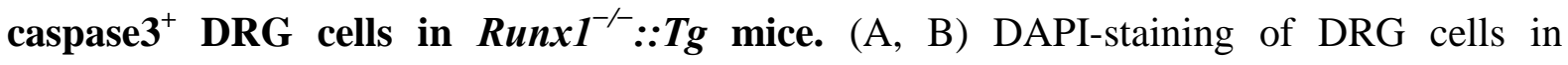
Runx $1^{+/+}:: \operatorname{Tg}(\mathrm{A})$ and $R u n x 1^{-/-}:: T g(\mathrm{~B})$ mice at E12.5. (C, D) Quantification of the total

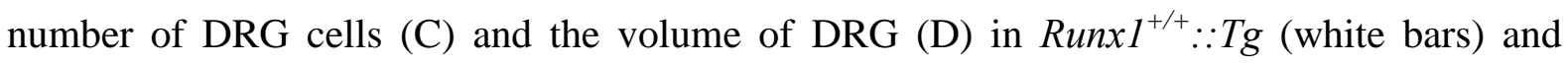
Runx $1^{-/-}:: T g$ (black bars) mice. (E-H) Immunoreactivity of caspase3 in DRG of $\operatorname{Runx}^{+/+} \because \operatorname{Tg}(\mathrm{E}, \mathrm{F})$ and $\operatorname{Runx}^{-/-} \because \operatorname{Tg}(\mathrm{G}, \mathrm{H})$ mice at E11.5 (E, G) and E12.5. (F, H). (I) Quantification of the number of caspase $3^{+}$DRG cells in Runx $1^{+/+}:: T g$ (white bars) and $\operatorname{Runx}^{-/-}: \because T g$ (black bars) mice at E11.5 and E12.5. Data are shown as mean \pm SEM. Scale bars: $100 \mu \mathrm{m}$ in $\mathrm{B}, \mathrm{E}-\mathrm{H}$.

Figure 4. Decrease of Islet1 ${ }^{+}$and $\mathrm{Hu}^{+}$DRG neurons in $\mathrm{Runx} \mathbf{1}^{-/-}:$Tg mice at E12.5.

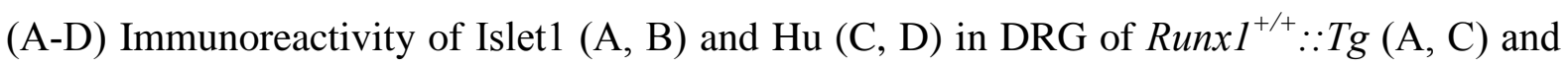
$\operatorname{Runx}^{-/-}: \because \operatorname{Tg}(\mathrm{B}, \mathrm{D})$ mice at E12.5. Boxed areas of immunoreactive neurons are shown at 
higher magnification in the insets at the left bottom of each panel. Islet1 is present in the nucleus and $\mathrm{Hu}$ is present mainly in the cytoplasm. (E, F) Quantification of the number of

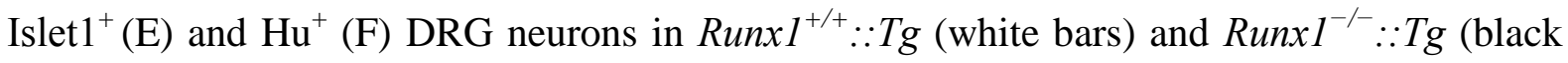
bars) mice at E12.5. Data are shown as mean \pm SEM; ${ }^{*} p<0.05$, ${ }^{* *} p<0.01$. Scale bar: $100 \mu \mathrm{m}$ in $\mathrm{D}$.

Figure 5. Increase of S-phase and G2/M-phase cells in $\operatorname{Runx1^{-/}}:: T g$ DRG at E12.5. (A) (A) Schematic illustration showing the experimental paradigm. (B, C) Double


$\operatorname{Runx}^{-/-}: \because \operatorname{Tg}(\mathrm{C})$ mice at E12.5. Boxed areas of immunoreactive neurons are shown at higher magnification in the insets at the left bottom of each panel. Arrowheads indicate BrdU/IDU positive nucleus (yellow) of the S-phase cells (S cells) and arrows indicate IDU positive nucleus (green) of the G2/M-phase cells (Leaving [L] cells) (see Materials and Methods). (D-F) Quantification of the number of S cells (D), L cells (E), and the length of S-phase (Ts) (F) in $R u n x 1^{+/}:: T g$ (white bars) and $R u n x 1^{-/-}:: T g$ (black bars) mice at E12.5. Data are shown as mean \pm SEM; ${ }^{*} p<0.05$. Scale bar: $100 \mu \mathrm{m}$ in $\mathrm{C}$.

Figure 6. Increase of Hes1 ${ }^{+}$cells in $\operatorname{Runx1}^{-/-}: \boldsymbol{T g}$ DRG at E12.5. (A-D) Immunoreactivity of Hes1 in DRG of Runx1 ${ }^{+/}: \because \operatorname{Tg}(\mathrm{A}, \mathrm{C})$ and $R u n x 1^{-/-}: \because \operatorname{Tg}(\mathrm{B}, \mathrm{D})$ mice at E11.5 (A, B) and E12.5 (C, D). Boxed areas of immunoreactive cells are shown at higher magnification in the insets at the left bottom of each panel. (E) Quantification of the number of Hes $1^{+}$DRG cells in $R u n x 1^{+/+}: \because T g$ (white bars) and $R u n x 1^{-/-}: \because T g$ (black bars) mice at E11.5 and E12.5. (F-H) Double immunostaining images of Runx1 (red in F, H) and Hes1 (green in G, H) in DRG of the wild-type mice at E12.5. Arrowheads indicate $\mathrm{Hes}^{+} / \mathrm{Runx} 1^{-}$nucleus $(\mathrm{G}, \mathrm{H})$ and arrows indicate $\mathrm{Hes} 1^{+} / \mathrm{Runx} 1^{+}$nucleus $(\mathrm{H})$ of DRG cells. Data are shown as mean $\pm \mathrm{SEM}$; ${ }^{*} p<0.05$. Scale bars: $100 \mu \mathrm{m}$ in A-D, $\mathrm{H}$.

Figure 7. Co-expression of Runx1 and activated-Notch1 in DRG at E12.5. (A-C) Double immunostaining images of Runx1 (red in A, C) and activated-Notch1 (green in B, C) in DRG of $R$ unx $1^{+/+}:: T g$ mice at E12.5. Arrowheads indicate activated-Notch $1^{+} / \operatorname{Runx} 1^{+}$cells. Scale bars: $100 \mu \mathrm{m}$ in $\mathrm{C}$.

Figure 8. Models of regulation of Hes1 transcription by Runx1. (A, B) Two possibilities of the regulatory mechanisms of Hes1 expression by Runx1. Runx $1^{+}$DRG neurons do not express Hes1 and repress Hes 1 expression in cells undergoing neuronal differentiation which 
adjoin the Runx $1^{+}$neurons (A). Runx1 suppresses Hes1 expression cell-autonomously within the same cells (B). (C) In Notch signal system, Hes1 expression is controlled by Notch1 intracellular domain (NICD) (Iso et al., 2003). When Delta-like1 (Dll1) binds to Notch1, NICD is disconnected from Notch1 and translocated into nucleus. Then NICD binds the nuclear protein CBF-1 and promotes Hes 1 transcription. It is possible that Runx 1 inhibits the Hes 1 transcription by binding to the transcriptional regulatory domain (TRD) of Hes1 in DRG neurons of $R u n x 1^{+/+}:: T g$ mice. In Runx $1^{-/}: \because T g$ mice, Runx1 does not bind the transcriptional regulatory domain of Hes 1 and DRG neurons continue to express Hes1. 
Figure 1

Click here to download high resolution image

Fig.1



G
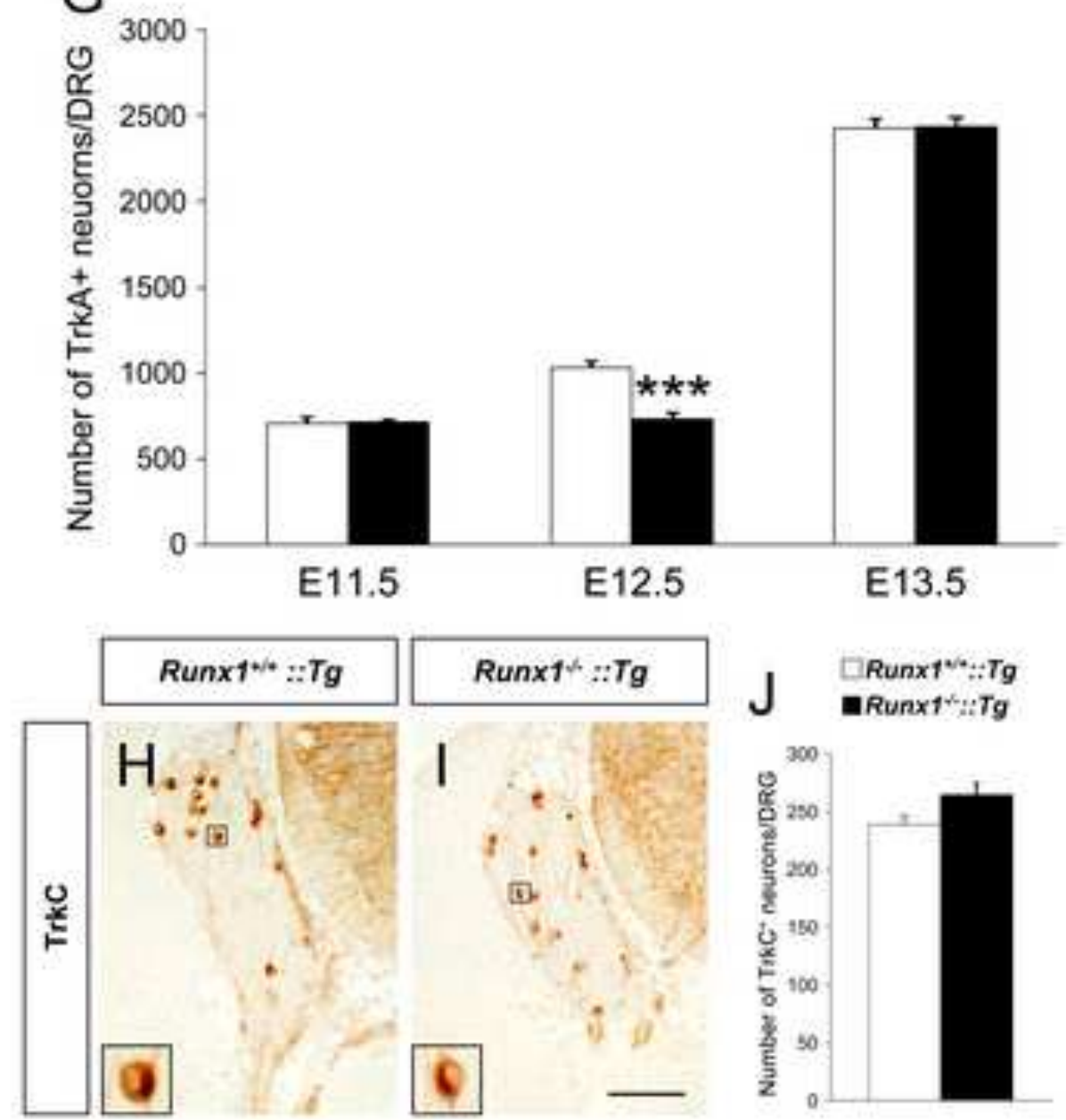
Fig.2

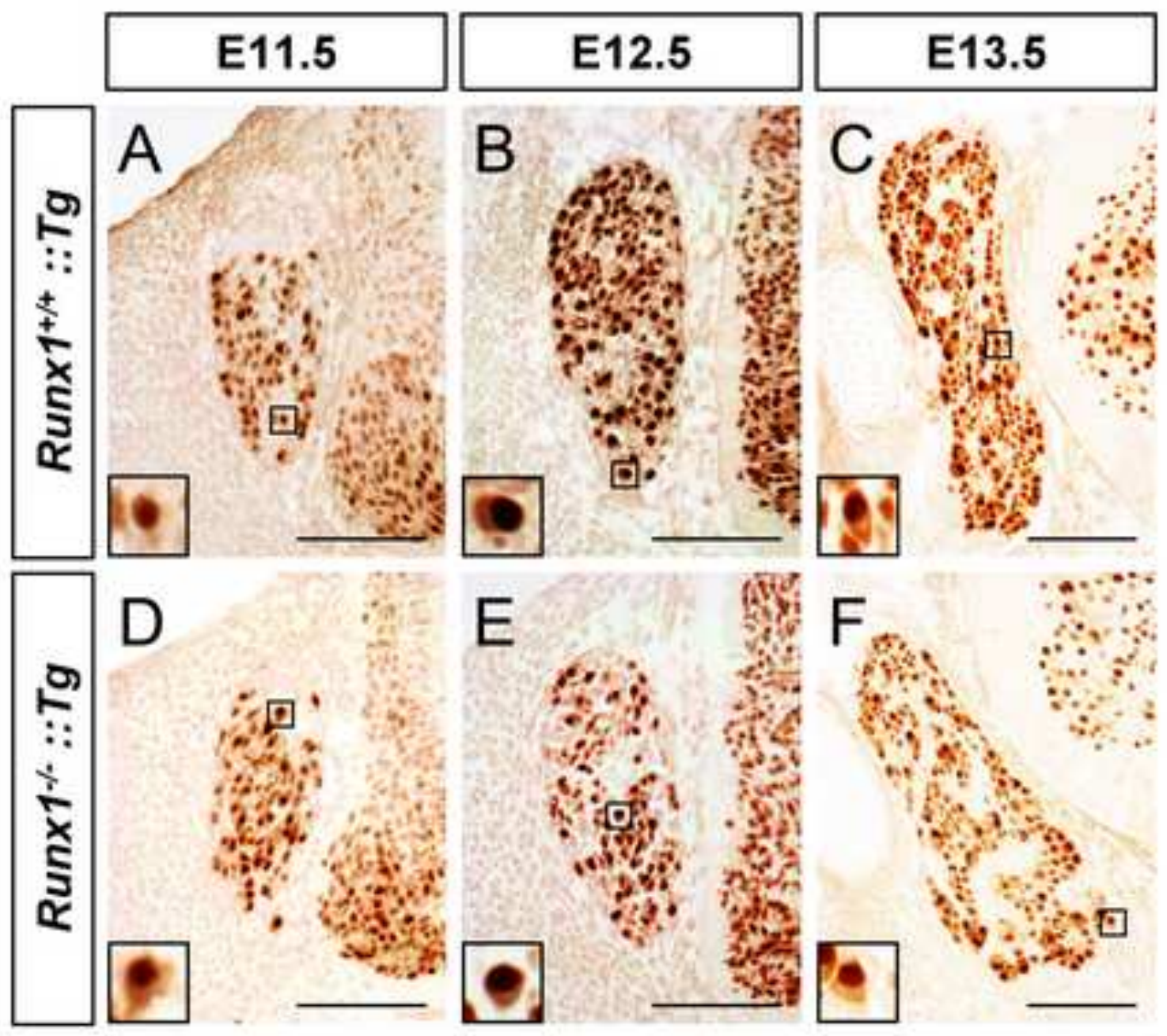

$G$

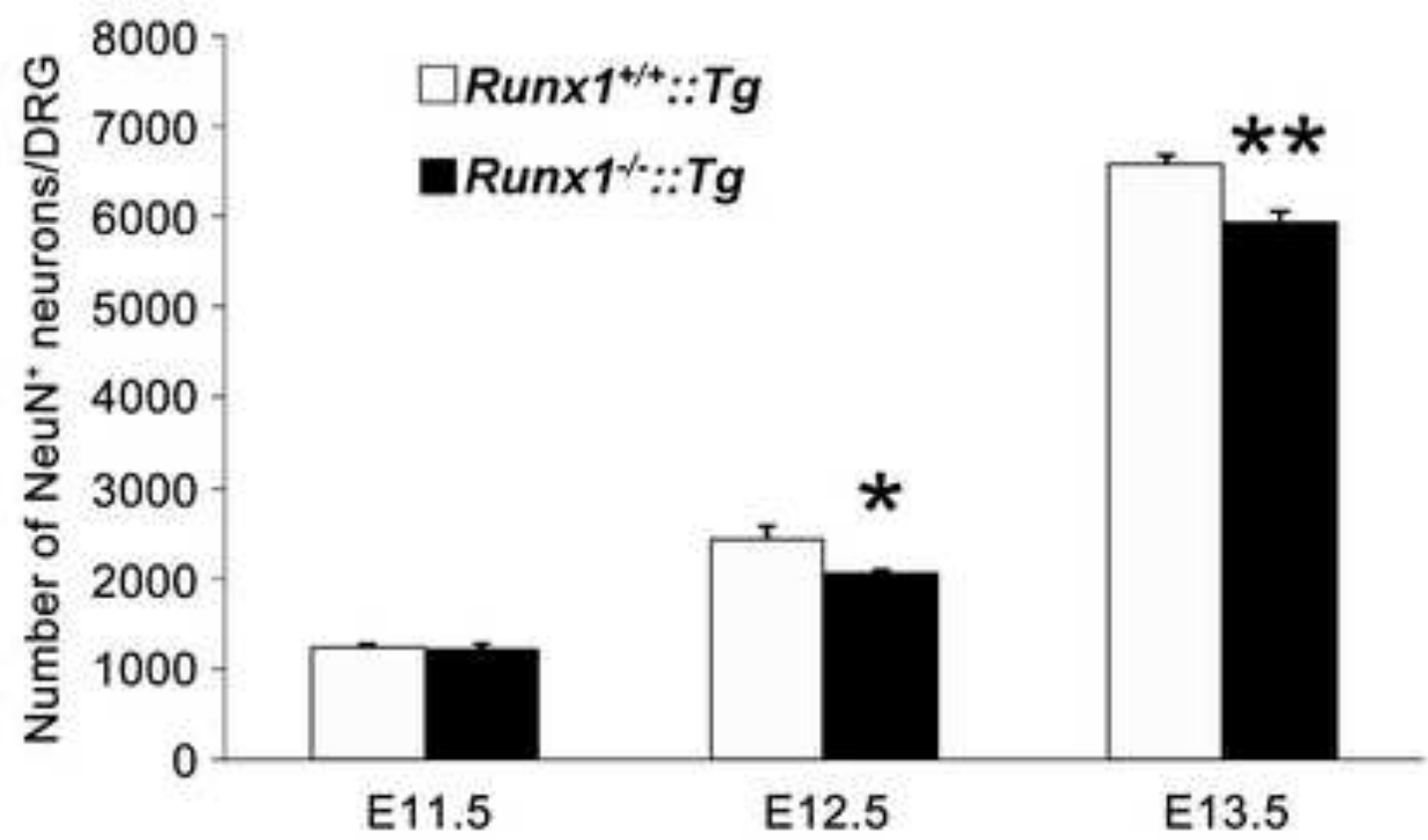


Click here to download high resolution image

Fig.3
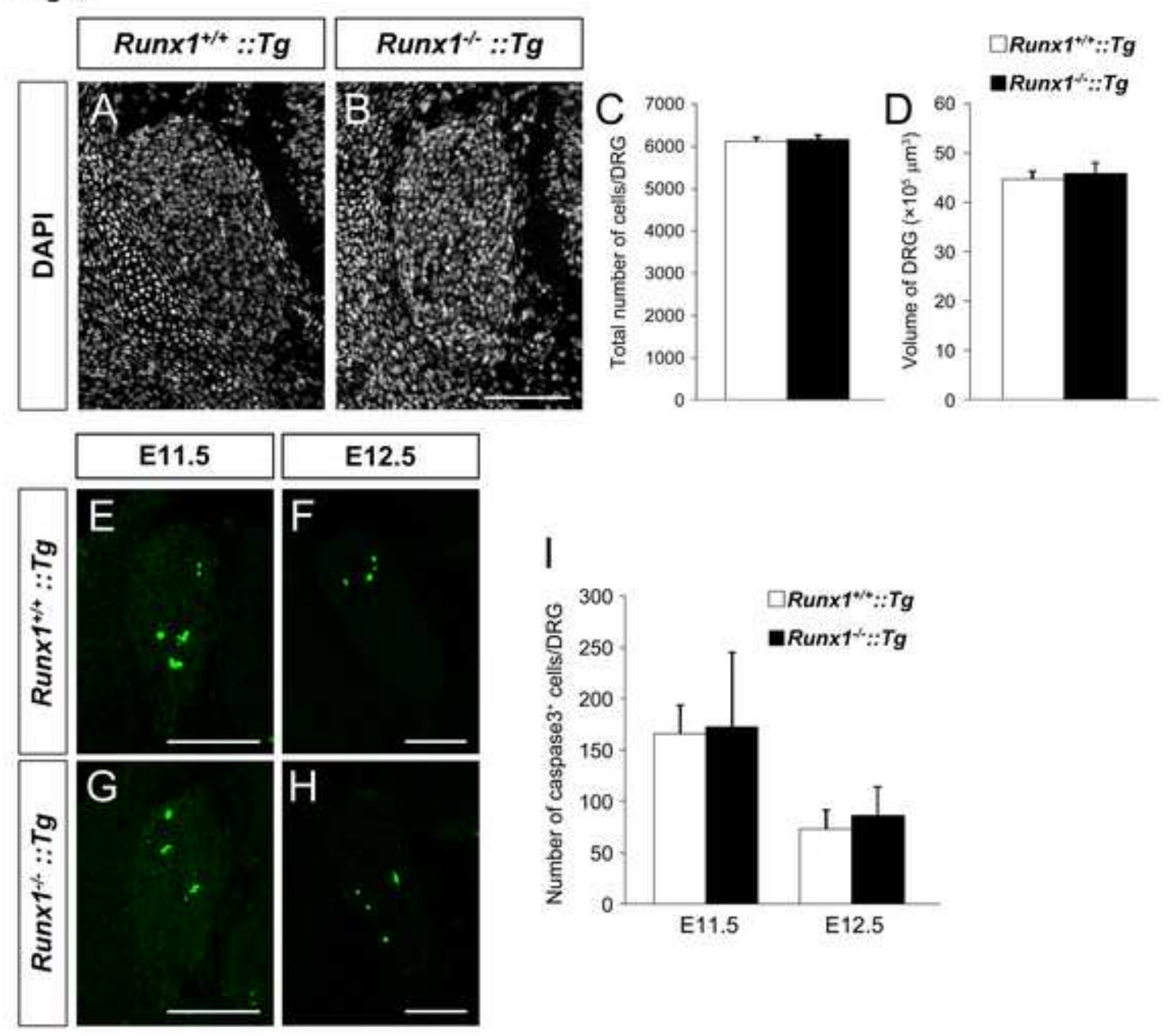
Fig.4

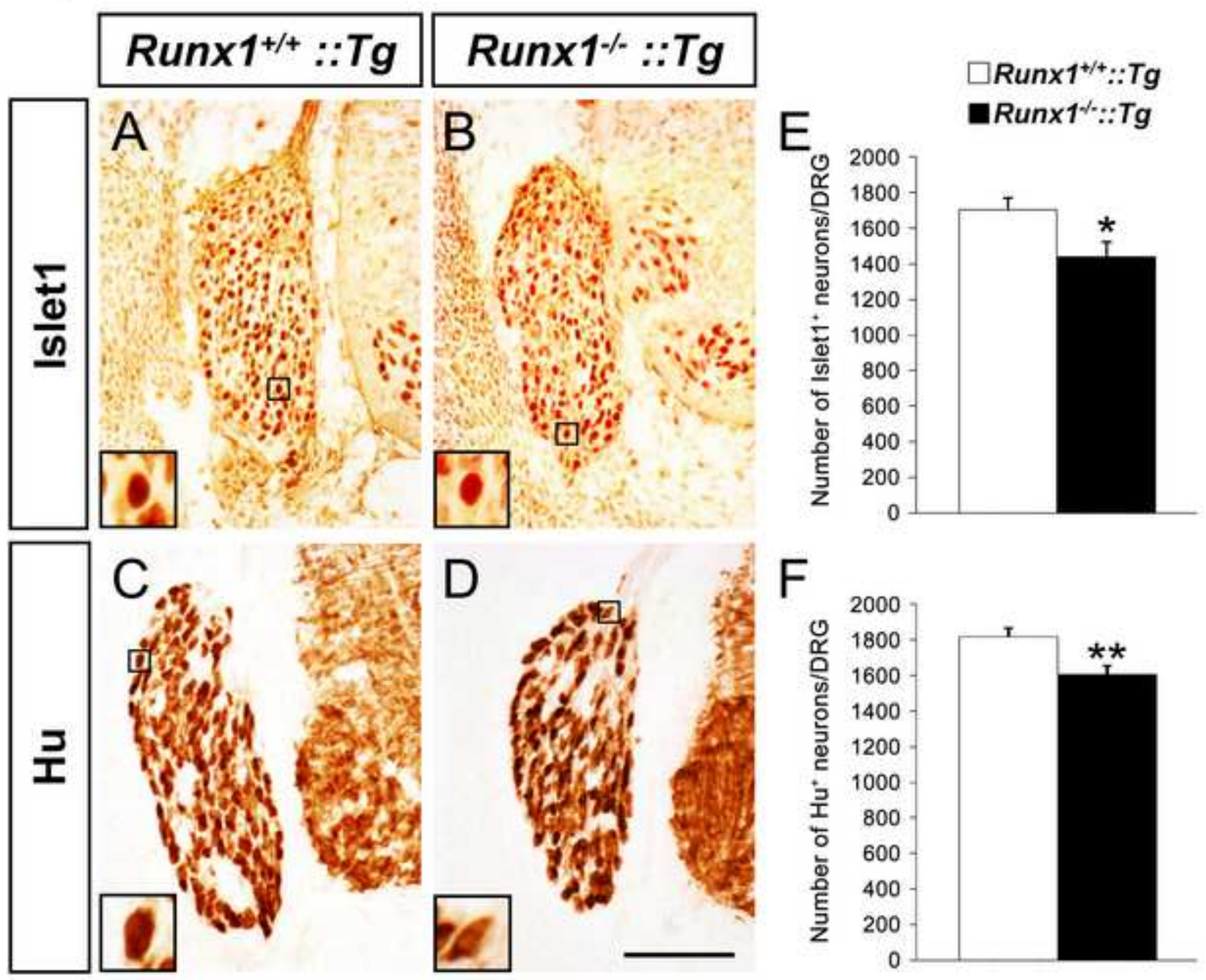


Figure 5

Click here to download high resolution image

Fig.5

A

IDU injection

BrdU injection

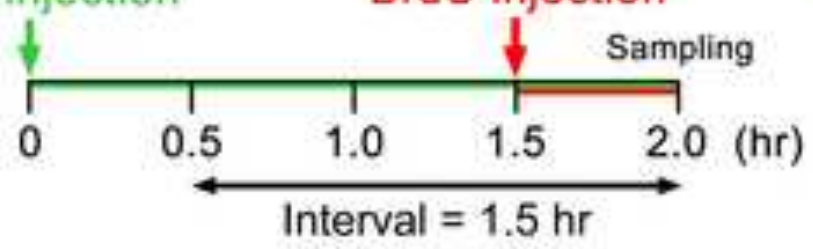

$S$ cells

(IDU $/ \mathrm{BrdU}^{+}$)

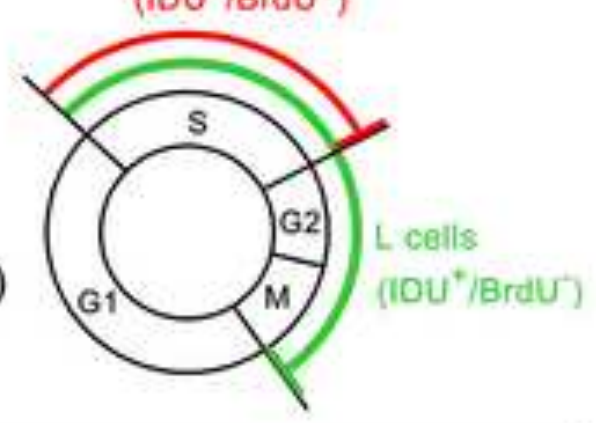

Runx $\times 1^{+/+}:: T g$
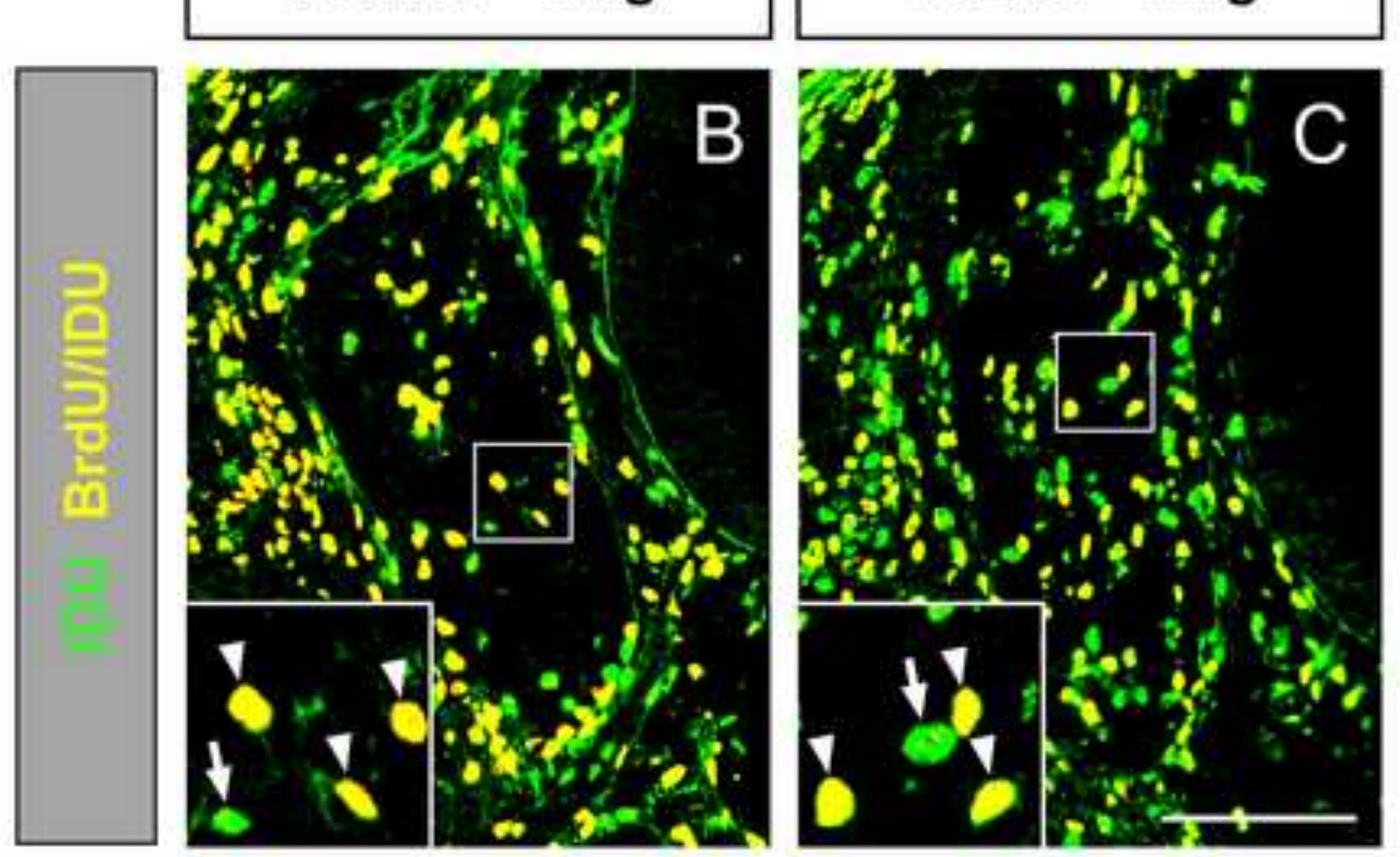

E

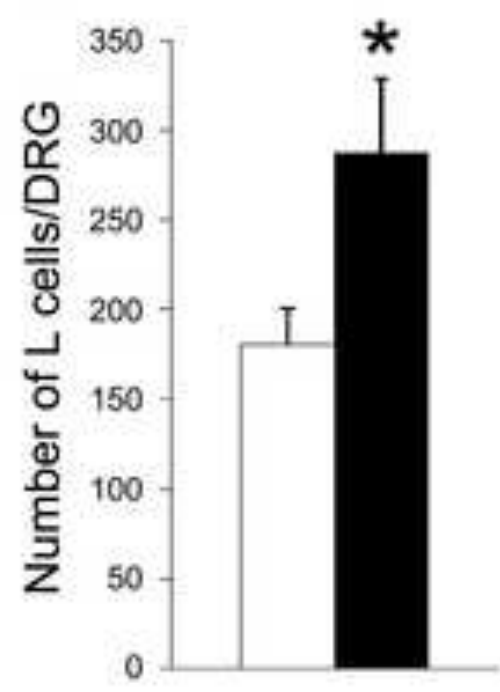

Runx $1^{\%}:: T g$

D

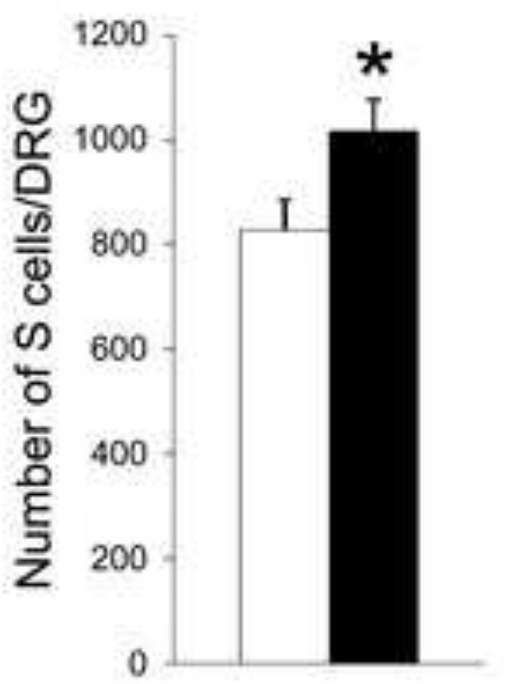

$\mathrm{F}$

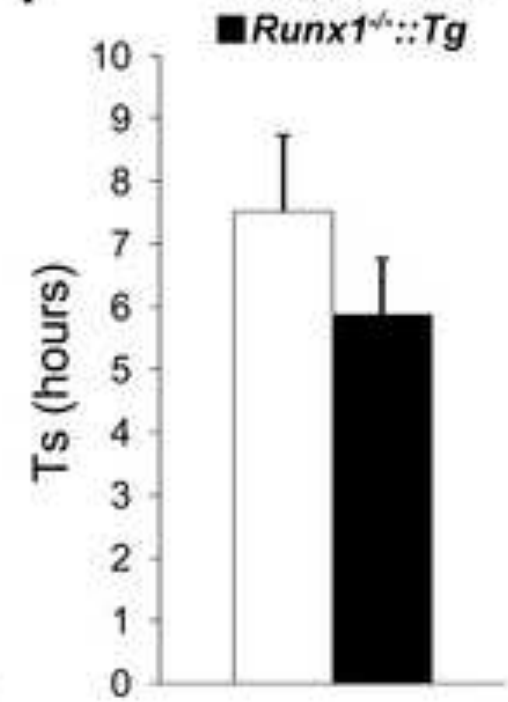

$\square$ Runx $1^{+/+*:: T g}$

a Runx $1^{\sqrt{*}:: T g}$ 
Fig.6


\section{E11.5 E12.5}


Fig. 7

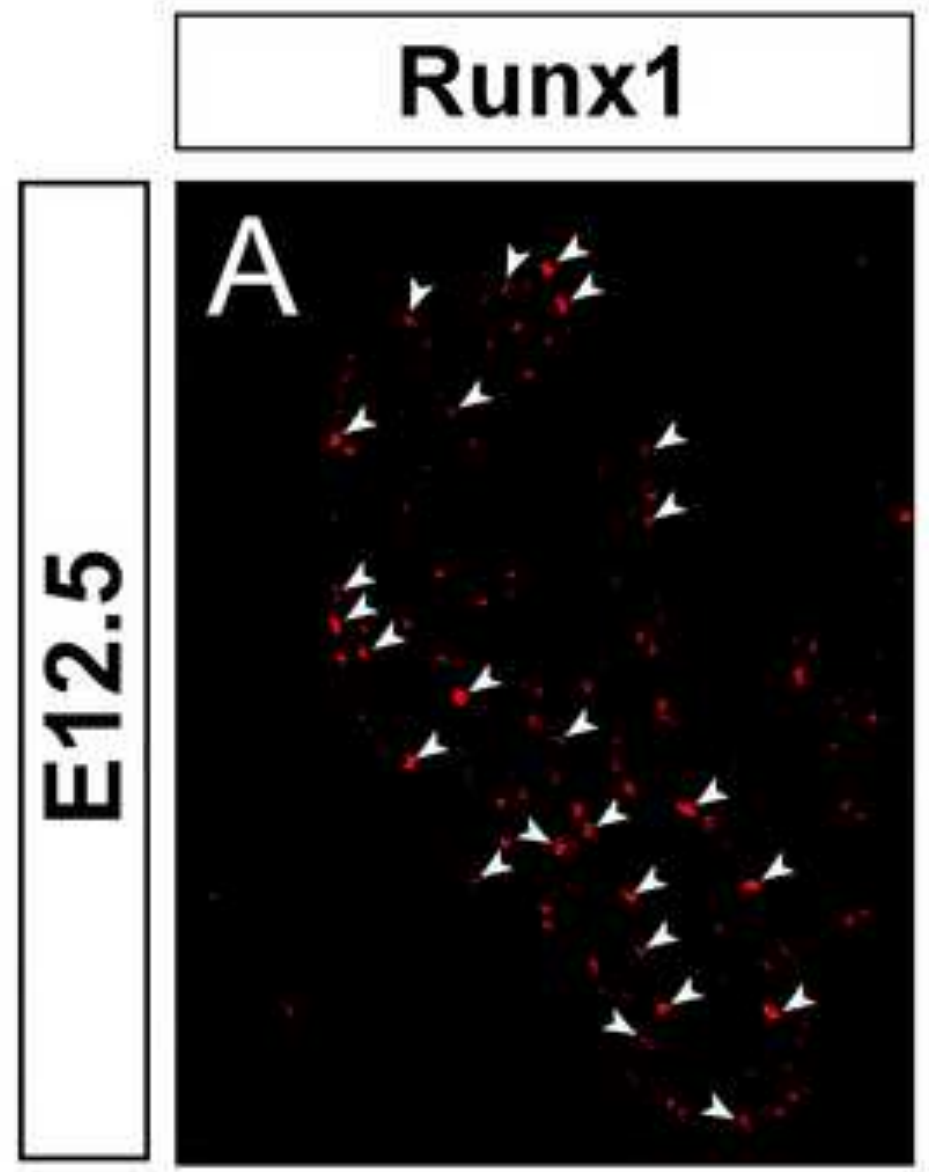

\section{Activated-Notch1}

\section{Merge}
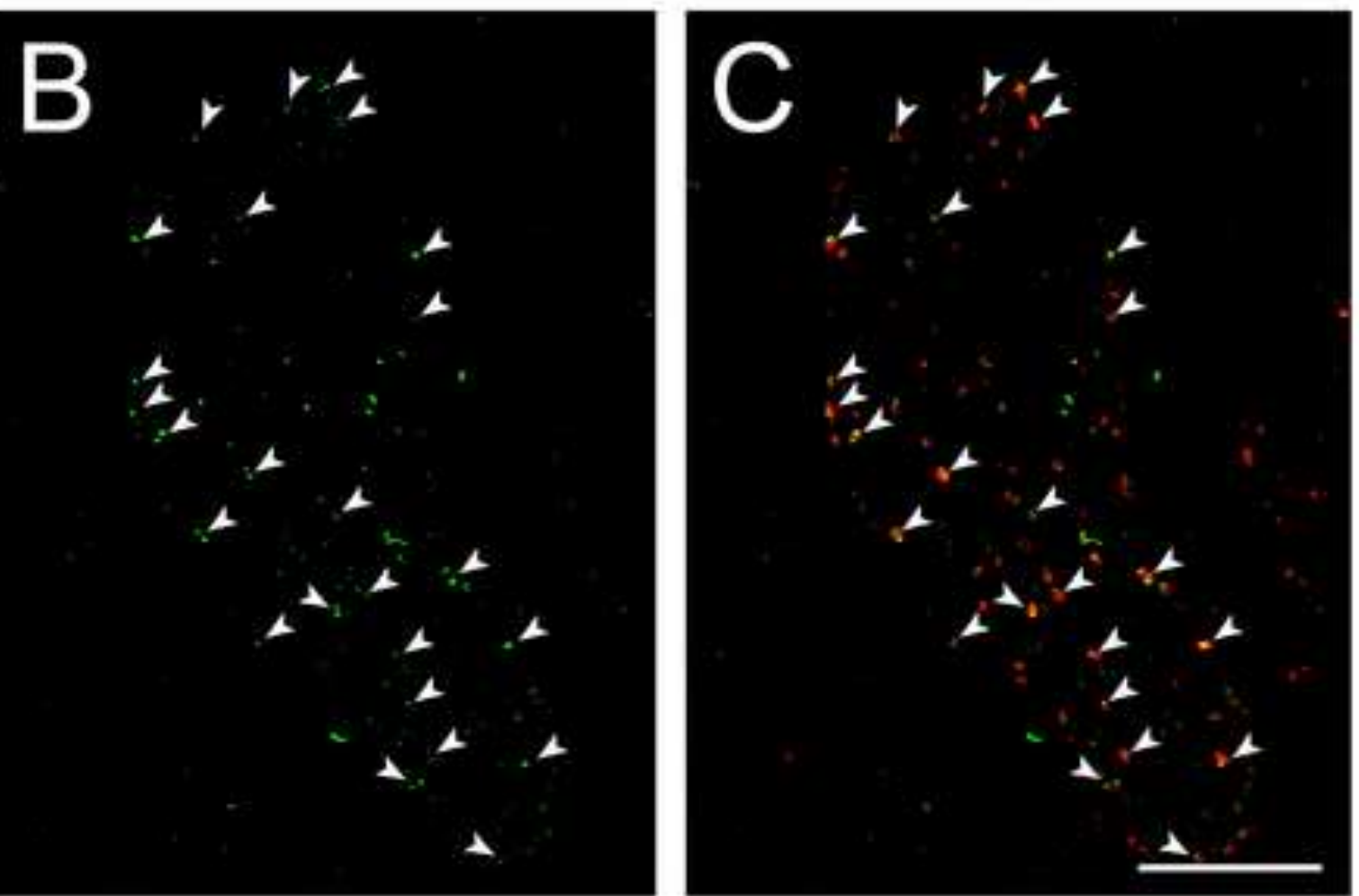


\section{Fig.8}
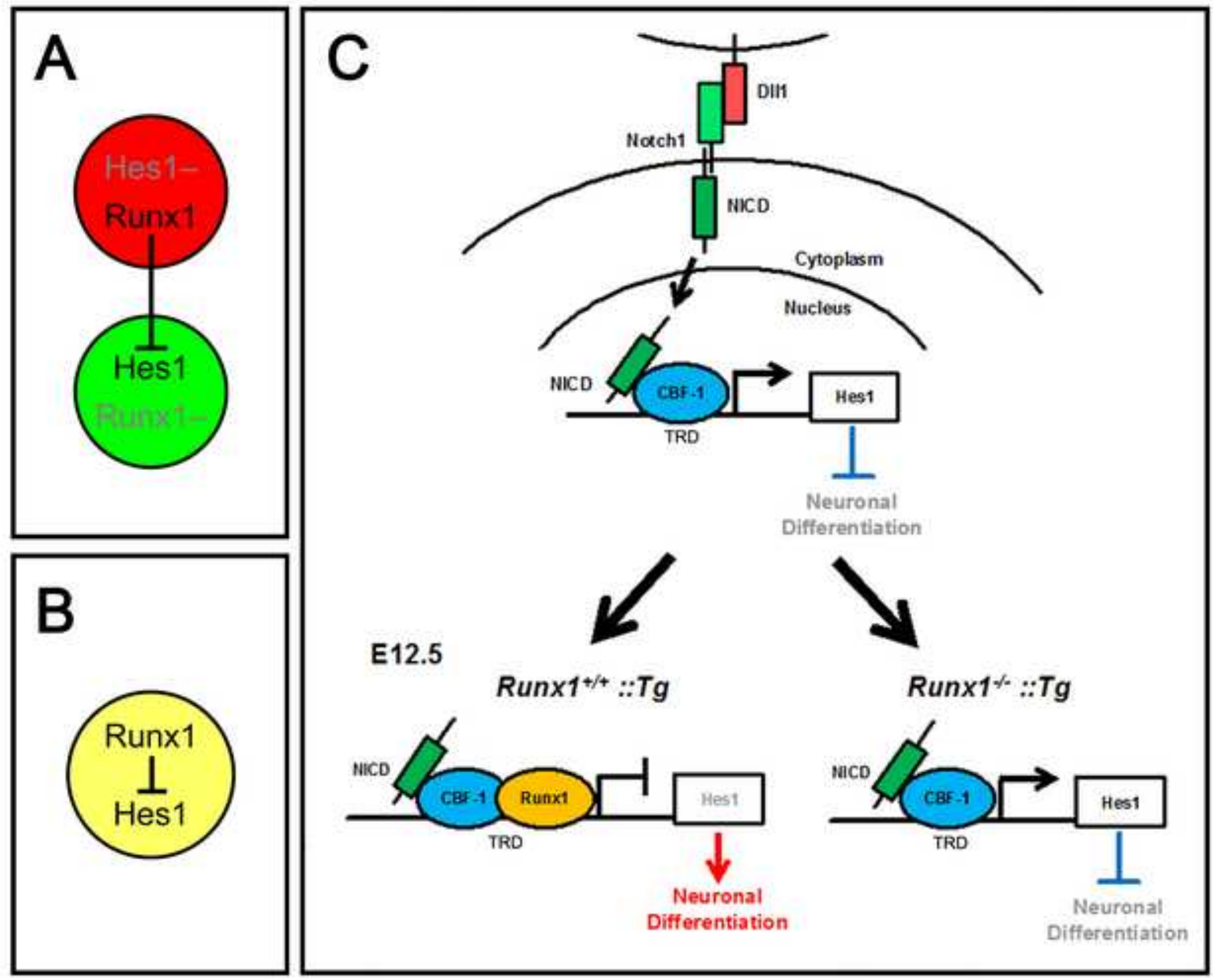
